\title{
DEVELOPMENT OF A FLOTATION METHOD FOR PRECONCENTRATION-SEPARATION OF TRACE AMOUNTS OF SOME METAL IONS IN PLANT TISSUES PRIOR TO THEIR FAAS DETERMINATIONS
}

\author{
M. Ghaedi*, A. Shokrollahi and M. Montazerozohori \\ Chemistry Department, University of Yasouj, Yasouj 75914-353, Iran \\ F. Marahel \\ Omidiyeh Azad University, Omidiyeh, Iran \\ M. Soylak \\ Chemistry Department, University of Erciyes, 38039 Kayseri, Turkey
}

Recebido em 29/5/09; aceito em 30/7/09; publicado na web em 11/1/10

\begin{abstract}
An efficient flotation method based on the combination of flame atomic absorption spectrometry (FAAS) and separation and preconcentration step for determination of $\mathrm{Cr}^{3+}, \mathrm{Cu}^{2+}, \mathrm{Co}^{2+}, \mathrm{Ni}^{2+}, \mathrm{Zn}^{2+}, \mathrm{Cd}^{2+}, \mathrm{Fe}^{3+}$ and $\mathrm{Pb}^{2+}$ ions in various real samples by the possibility of applying bis(2-hydroxyacetophenone)-1,4-butanediimine (BHABDI) as a new collector was studied. The influence of $\mathrm{pH}$, amount of BHABDI as collector, sample matrix, type and amount of eluting agent, type and amount of surfactant as floating agent, ionic strength and air flow rates i.e. variables affecting the efficiency of the extraction system was evaluated. It is ascertained that metal ions such as iron can be separated simultaneously from matrix in the presence of $0.012 \mathrm{mM}$ ligand, $0.025 \%$ (w/v) of CTAB to a test sample of $750 \mathrm{~mL}$ at $\mathrm{pH}$ 6.5. These ions can be eluted quantitatively with $6 \mathrm{~mL}$ of $1.0 \mathrm{~mol} \mathrm{~L}^{-1} \mathrm{HNO}_{3}$ in methanol which lead to the enrichment factor of 125 . The detection limits for analyte ions were in the range of 1.3-2.4 $\mathrm{ng} \mathrm{mL}^{-1}$. The method has been successfully applied for determination of trace amounts of ions in various real samples.
\end{abstract}

Keywords: bis(2-hydroxyacetophenone)-1,4-butanediimine; metal; flotation.

\section{INTRODUCTION}

The total trace element levels have become of prime importance to aid both the clinical in the diagnosis and treatment of variety of diseases and the life science researcher in the investigation of the role of trace elements in health and disease. ${ }^{1-4}$ The lack of these microelements in biological systems can cause many diseases and illnesses. However, the excess quantities of some of these elements can induce different harmful consequence. ${ }^{5-7}$

At the present time, the most common methods for mineral analyses are flame atomic absorption spectrometry (FAAS), spectrophotometry or inductively coupled plasma mass spectrometry (ICP-MS). ICP-based techniques require expensive instrumentation and maintenance. However, the simultaneous determination of these ions by the use of the traditional UV-visible absorption molecular spectroscopy as another possibility is difficult due to the fact that the absorption region and the superimposed curves are not suitable for quantitative evaluation. ${ }^{8-12}$ In most complex samples spectral overlap is often a serious problem. Usually the FAAS with slight spectral interference as and even accessible instrument apply for this purpose. Attempts of some authors to perform their determination directly from the sample solution by FAAS have been failed due to various factors, particularly their low concentrations and matrix effects. ${ }^{13-15}$ Many authors indicated that matrix interferences are possible to be overcome by addition of different matrix modifiers [16-19] as well as the use of separation procedures using diverse organic reagents. ${ }^{20-26}$ Some of the extraction methods suffer from inconveniences such as, lengthy separation, limitation of the volume of sample solution investigated, time consuming, multi stage, lower enrichment factor and consumption of organic harmful solvents which can be overcome by replacement of filtration or centrifugation by flotation. ${ }^{27-29}$

\footnotetext{
*e-mail: ghaedims@yahoo.com
}

Flotation as a preconcentration method has unique advantages such as rapidity and excellent recoveries of investigated trace elements, simple and inexpensive equipments and ability to analyze a large volume of sample solution and to obtain a greater preconcentration factor than the conventional carrier precipitation technique. The small amount of a surfactant and the tiny air bubbles require to perform the proper flotation prevent serious contamination risks, which could be manifested by the high blank value. Many factors influence to perform a proper flotation, but an important role has the collector with its colloid nature. ${ }^{30-34}$ According to our knowledge there is still not reported any method in the literature, based on the simultaneous flotation of transition and heavy metal ions using Schiff's bases ligand. Therefore, in detail it was decided to develop an efficient method for the extraction and preconcentration of trace amounts of some metal ions from aqueous media using bis(2-hydroxyacetophenone)-1,4-butanediimine (BHABDI) and determination by FAAS.

\section{EXPERIMENTAL}

\section{Instruments}

The measurements of metal ions were performed with a Shimadzu 680 AA spectrometer equipped with a hollow cathode lamp and a deuterium background corrector, at respective wavelengths (resonance line) using an air-acetylene flame. The instrumental parameters were those recommended by the manufacturer. A Metrohm $691 \mathrm{pH} /$ Ion meter with a combined glass-calomel electrode was used for adjustment of test solution $\mathrm{pH}$.

\section{Reagents}

Acids and bases were of the highest purity available from Merck and were used as received. Doubly distilled deionized water was used 
throughout. Nitrate salts of lead, cadmium, mercury, cobalt, iron, nickel, copper, zinc, magnesium, calcium, strontium, barium, silver, sodium and potassium (all from Merck, Darmstadt, Germany) were of the highest purity available and used without any further purification. The $\mathrm{pH}$ adjustment was done by addition of dilute nitric acid or sodium hydroxide to sample for preparing the desired $\mathrm{pH}$ sample solution.

\section{Preparation of Bis (2-hydroxyacetophenone)- 1, 4-butanediimine (BHABDI)}

$2 \mathrm{mmol}$ of 2-hydroxy acetophenone in $50 \mathrm{~mL}$ of ethanol was added to $1 \mathrm{mmol}$ of 1,4-butanediamine in $50 \mathrm{~mL}$ of ethanol. The reaction mixture was refluxed for $6 \mathrm{~h}$. Then the mixture was kept in refrigerator overnight and then filtered to give the product as yellow crystals ( $89 \%$ yields). The product was characterized by analytical and spectral data. Elemental analysis, $\% \mathrm{C}_{20} \mathrm{H}_{24} \mathrm{~N}_{2} \mathrm{O}_{2}: \mathrm{C}, 74.04 ; \mathrm{H}$, 7.46; N, 8.64; found: C, 74.21; H, 7.38; N, 8.69. IR( $\left.\mathrm{KBr}, \mathrm{cm}^{-1}\right)$ : 3433(bs, vOH), 3048(w, CH- Aromatic), 2933(w, CH- Aliphatic), 2866(w, CH- Aliphatic), 1613(-C=N), 1554(C=C), 1492(m, C=C), 1444(m), 1382(w), 1325(m), 1311(m), 1231(m), 1261(m, vC-N), 1159(s), 1130(m), 1068(m, C-O), 1009(m, C-O), 948(m), 841(s), 836(m), 761(s), 746(s), 633(m), 560(m), 526(m), 474(m), 443(w).

The structure of ligand is presented in Scheme 1.

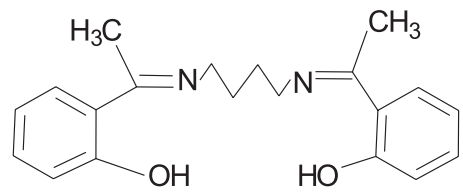

Scheme 1. The structure of the ligand

\section{Spectrophotometric titration's}

Standard stock solutions of ligands $\left(1.0 \times 10^{-3} \mathrm{~mol} \mathrm{~L}^{-1}\right)$ and metal ions $\left(1.0 \times 10^{-3} \mathrm{~mol} \mathrm{~L}^{-1}\right)$ were prepared by dissolving appropriate and exactly weighed (with an accuracy of $0.0001 \mathrm{~g}$ ) pure solid compounds in pre-calibrated $25.0 \mathrm{~mL}$ volumetric flasks and diluted to the mark with acetonitrile. Working solutions were prepared by appropriate dilution of the stock solutions. Titration of the ligand solution $\left(3.84 \times 10^{-5} \mathrm{~mol} \mathrm{~L}^{-1}, 2.6 \mathrm{~mL}\right)$ was carried out by the addition of microliter amounts of a concentrated standard solution of the metal ion in acetonitrile $\left(1.0 \times 10^{-3} \mathrm{~mol} \mathrm{~L}^{-1}\right)$ using a pre-calibrated micropipette, followed by absorbance intensity reading at $25.0^{\circ} \mathrm{C}$ at the related maximum wavelength. Since the volume of titrant added during titration was negligible (at the most $0.05 \mathrm{~mL})$ as compared with the initial volume of the ligands $(2.6$ $\mathrm{mL}$ ), no volume correction was carried out. ${ }^{35}$

\section{Flotation-separation procedure}

A combined glass electrode was immersed into a $1 \mathrm{~L}$ beaker of sample solution containing $0.5 \mu \mathrm{g} \mathrm{mL}-1$ of each ion. Then, 6 $\mathrm{mL}$ of saturated $\mathrm{KNO}_{3}$ solution and $0.025 \%(\mathrm{w} / \mathrm{v})$ of CTAB and $0.012 \mathrm{mM}$ of BHABDI were added and the $\mathrm{pH}$ of medium was carefully adjusted to 6.5 with $\mathrm{KOH}$ solution. After stirring for 15 min, the mixture was transferred quantitatively to the flotation cell and filled to the $750 \mathrm{~mL}$ mark with DDW. An air stream $(50 \mathrm{~mL}$ $\min ^{-1}$ ) was kept flowing for 2-4 min to raise the foam layer to the water surface. A foamy layer was thus obtained and the aqueous solution in the cell became clear. Then the glass pipette tube was immersed into the cell through the foam layer and a water sample $(8 \mathrm{~mL})$ was sucked off and used for FAAS.

\section{Application of real samples}

All plant samples (Citrus aurantium L., Rose - Canina, Fumaria parviflora, Allium Cepal, Tomato) were purchased from Gachsaran Iran. Afterwards, they were taken in small mesh. A $40 \mathrm{~g}$ vegetable sample was heated in silica crucible for $3 \mathrm{~h}$ on a hot plate and the charred material was transferred to furnace for overnight heating at $650{ }^{\circ} \mathrm{C}$. The residue was cooled and treated with $10.0 \mathrm{~mL}$ concentrated nitric acid and $3 \mathrm{~mL} 30 \% \mathrm{H}_{2} \mathrm{O}_{2}$ again kept in furnace for $2 \mathrm{~h}$ at the same temperature so that no organic compound traces are left. The final residue was treated with $3 \mathrm{~mL}$ concentrated hydrochloric acid and 2-4 $\mathrm{mL} \mathrm{70 \%} \mathrm{(w/V)} \mathrm{perchloric}$ acid and evaporated to fumes, so that all the metals change to respective ions. The solid residue was dissolved in water, filtered and its $\mathrm{pH}$ was kept at 6.5 and made up to $200 \mathrm{~mL}$ by addition of $\mathrm{NaOH}$. The dissolved solution was suitably diluted and metals concentration was determined after application of proposed procedure using FAAS. ${ }^{36,37}$

\section{RESULTS AND DISCUSSION}

BHABDI with two oxygen and two nitrogen donating Schiff's base) has low solubility in water at $\mathrm{pH} 7$ and is susceptible for trace metal enrichment. Although the Schiff base ligand form very stable complexes with transition metal ions. However, little is known about their complex formation with metal ions in sample solution. The unique nature of Schiff base-N-donor is enhanced by the existence of widely spread p-conjugation system. Therefore, in order to obtain a clue about the stability constant, the complexation of ligand with these ions were investigated spectrophotometrically and respective titration curve and mole ratio plots for lead and zinc ions are presented in Figure 1. As it can be seen, the obvious changes in spectra by addition of metal ions to ligand solutions are an indication of strong interaction between metal ions and ligand. Further analyzing the absorbance at maximum wavelengths using KINFIT program the stoichiometry and stability constant of (BHABDI) respective complexes has been evaluated and the stability constants for different complexes are presented in Table 1 .

The extraction mechanism corresponds to a cation exchange, in which a complex has a stoichiometric formula ( $\mathrm{ML}$ or/and $\mathrm{ML}_{2}$ ) is formed in the organic phase, and also liberating at the same time 2 mole $\mathrm{H}^{+}$ions in aqueous phase. The results of the present investigation shows that the reagent $\mathrm{L}$ can be successfully used for the quantitative extraction of heavy metals ions.

Table 1. Logarithm of ordinary stability constants for the interaction of some metal ions with the BHABDI in non aqueous solution

\begin{tabular}{lcccc}
\hline Solvent & Metal ion & $\mathrm{M}$ & $\mathrm{L}$ & $\log \beta$ \\
\hline $\mathrm{AN}$ & $\mathrm{Cu}^{2+}$ & 1 & 1 & $5.000 \pm 0.242$ \\
& & 1 & 2 & $4.000 \pm 0.181$ \\
& $\mathrm{Ni}^{2+}$ & 1 & 1 & $5.001 \pm 0.262$ \\
& & 1 & 2 & $4.001 \pm 0.204$ \\
& $\mathrm{Co}^{2+}$ & 1 & 1 & $4.885 \pm 0.226$ \\
& & 1 & 2 & $4.081 \pm 0.188$ \\
$\mathrm{MeOH}$ & & 1 & 1 & $5.918 \pm 0.288$ \\
& $\mathrm{Zn}^{2+}$ & 1 & 2 & $5.003 \pm 0.26$ \\
& & 1 & 1 & $4.999 \pm 0.258$ \\
& $\mathrm{Fe}^{3+}$ & 1 & 2 & $4.047 \pm 0.202$ \\
& & 1 & 1 & $5.008 \pm 0.415$ \\
& $\mathrm{Cr}^{3+}$ & 1 & 2 & $3.998 \pm 0.149$ \\
\hline
\end{tabular}


(a)

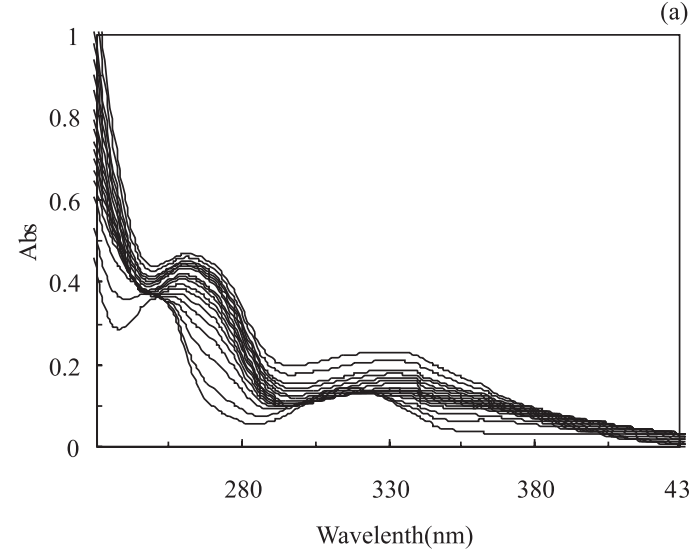

(b)

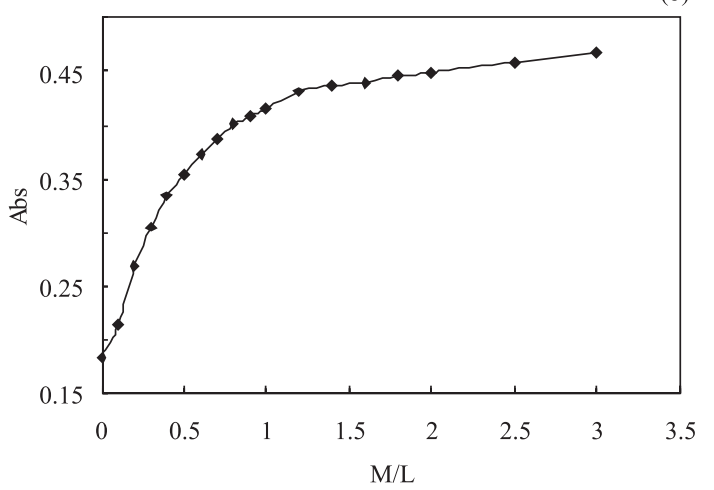

Figure 1. UV-visible spectra for titration of $L\left(3.84 \times 10^{-5} \mathrm{~mol} \mathrm{~L}^{-1}\right)$ with $\mathrm{Cu}^{2+}$ $\left(1.00 \times 10^{-3} \mathrm{~mol} \mathrm{~L}^{-1}\right)$ in acetonitrile $\left(T=25^{\circ} \mathrm{C}\right.$ and $\left.I=0.05 \mathrm{~mol} \mathrm{~L}^{-1}\right)$ : (a) the molar ratio plot in $\lambda_{\max }=263$; (b) the corresponding computer fitted curve of absorbance vs. $\mathrm{Cu}^{2+} / \mathrm{L}$

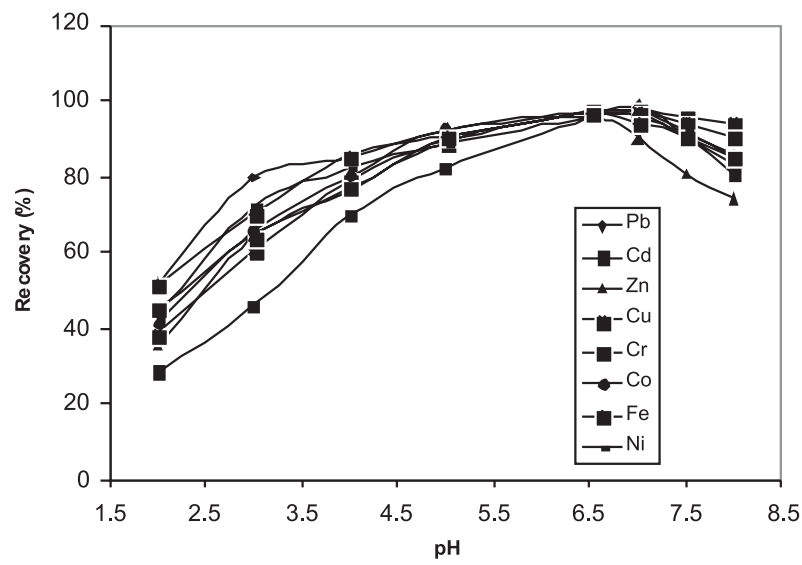

Figure 2. Effect of $\mathrm{pH}$ on the recoveries of analyte ions by flotation $(\mathrm{N}=3)$

\section{Effect of pH}

Flotation yield depends on the $\mathrm{pH}$ at which complex formation occurs and plays a unique role on metal-chelate formation and subsequent extraction. Flotation of $\mathrm{Cr}^{3+}, \mathrm{Cu}^{2+}, \mathrm{Co}^{2+}, \mathrm{Ni}^{2+}, \mathrm{Zn}^{2+}$, $\mathrm{Cd}^{2+}, \mathrm{Fe}^{3+}$ and $\mathrm{Pb}^{2+}$ ions were carried out in solutions $\mathrm{pH}$ ranging from 2 to 8 and respective results are presented in Figure 2. As it is obvious, out of the $\mathrm{pH}$ of 6.5 , the recoveries of all cations are sharply decreased, most probability due to protonation of BHA$\mathrm{BDI}$ in acidic media and possible hydrolysis of cations at the $\mathrm{pH}$ of greater than 6.5. The acid dissociation constant of BHABDI at $\mathrm{pH} 6.5$ was very low with a Ka value of $10^{-4}$, so the efficiencies decreased with increasing acidity. At $\mathrm{pH}$ of 6.5 , BHABDI is deprotonated and its complexes with the metal ions of interest have higher stability. In subsequent experiments adjustment of $\mathrm{pH}$ on 6.5 was recommended.

\section{Type and amount of surfactant}

A surfactant is usually used to float such complexes to the surface of sample solution effectively. The role of the surfactant in this case is to float the material of complex or precipitate to the surface of a solution by foams after the surface of floating material is changed from hydrophilic to hydrophobic. Hydrophobic materials can more effectively secede from an aqueous solution than hydrophilic materials. Also the foams of surfactant support the floated material and prevent the redistribution so that the flotation efficiency increases for the effective flotation. To select the most effective tenside among several cationic, anionic and non-ionic surfactants, a number of tests under previously optimized conditions were carried out and respective results are presented in Table 2. As it was seen, the effective flotation was shown in by the addition of cationic CTAB the metal ions complexes. This is because of high possibility to form the anionic four coordinated complex of such metal ions with Schiff base ion.

Therefore, the addition of cationic surfactant improves the efficiencies of flotation, but the efficiencies are lowered by anionic surfactant. The flotation efficiency was so significantly affected by the amount of surfactant that the change of absorbance was obtained in the floated solution by changing the CTAB concentration from 0.005 to $0.03 \%(w / v)$. It can be seen from Figure 3, that maximum efficiency were obtained by addition of CTAB until $0.025 \%(\mathrm{w} / \mathrm{v})$. But if a large volume were added, then some problems occurred due to the amount of foam in this flotation technique. This result might be related to the presence of the high amount of surfactant, resulting in an increase in the volume of the surfactant-rich phase. In addition, the viscosity of the surfactant-rich phase increases, leading to poor sensitivity. ${ }^{34,35}$ At lower CTAB concentrations (below $0.005 \% \mathrm{w} / \mathrm{v}$ ), the preconcentration efficiency of the complex was very low, probably due to assemblies that were inadequate to quantitatively entrap the hydrophobic complex and float the complex. ${ }^{36}$

Table 2. Effect of type of surfactant on sensitivity for $2.0 \mu \mathrm{g} \mathrm{mL}-1$ of interest ion, $\mathrm{pH} 6.5,0.012 \mathrm{mM}$ BHABDI, $0.025 \%$ (w/v) of each surfactant

\begin{tabular}{lcccccccc}
\hline & \multicolumn{9}{c}{ Recovery, \% } \\
\hline Surfactant & $\mathrm{Pb}$ & $\mathrm{Cd}$ & $\mathrm{Zn}$ & $\mathrm{Cu}$ & $\mathrm{Cr}$ & $\mathrm{Co}$ & $\mathrm{Fe}$ & $\mathrm{Ni}$ \\
SDS & 88.5 & 63.9 & 90.6 & 38.4 & 81.3 & 71.7 & 78.2 & 72.4 \\
CTAB & 98.6 & 95.9 & 96.3 & 97.7 & 98.6 & 98.7 & 97.0 & 97.6 \\
Triton & 91.5 & 62.7 & 77.8 & 96.3 & 98.3 & 76.6 & 48.2 & 76.7 \\
DTAB & 93.5 & 87.3 & 94.3 & 99.2 & 95.6 & 89.5 & 92.7 & 94.2 \\
\hline
\end{tabular}




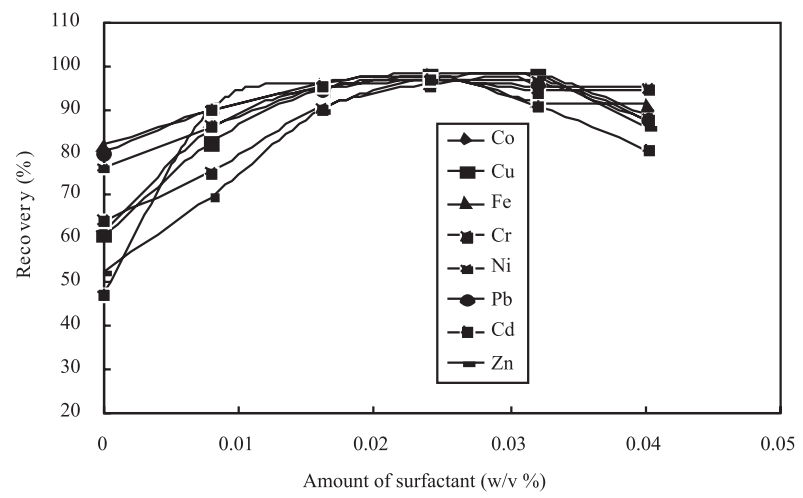

Figure 3. Effect of amount of CATB on the recoveries of analyte ions $(N=3)$

\section{Bubbling by air}

Air gas plays an important role to float the ion pairs of analytes by bubbling. The efficiency of flotation and the shapes of floated materials depend on the bubble size of air gas which is determined by the flow rate of the gas through a porous plate of fritted glass as well as the hole sizes in the plate. Such bubbles float to the surface of solution by making an interface between surface-activated complexes and bulk aqueous solution. The decrease was due to the dissociation and redistribution complexes into bulk solution. Such phenomena happened by the weak bonds in complexes as well as weakening of the hydrophobic activity of the surfactant on the surface of complex by the strong agitation for a long time. ${ }^{37}$

It was occurred to us that after bubbling for $5 \mathrm{~min}$ at $50 \mathrm{~mL} \mathrm{~min}^{-1}$ air the maximum flotation efficient were achieved. A small amount of methanol was added to the solution for the effective generation of numerous tiny bubbles. ${ }^{37}$

\section{Effect of BHABDI concentration on recoveries of the analytes}

The BHABDI was employed as a complexing agent for $\mathrm{Cr}^{3+}, \mathrm{Cu}^{2+}$, $\mathrm{Co}^{2+}, \mathrm{Ni}^{2+}, \mathrm{Zn}^{2+}, \mathrm{Cd}^{2+}, \mathrm{Fe}^{3+}$ and $\mathrm{Pb}^{2+}$ ions flotation. For this study, 750 $\mathrm{mL}$ of a solution containing $0.5 \mu \mathrm{g} \mathrm{mL} \mathrm{mL}^{-1}$ of $\mathrm{Cr}^{3+}, \mathrm{Cu}^{2+}, \mathrm{Co}^{2+}, \mathrm{Ni}^{2+}, \mathrm{Zn}^{2+}$, $\mathrm{Cd}^{2+}, \mathrm{Fe}^{3+}$ and $\mathrm{Pb}^{2+}$ ions in $0.025 \%$ (w/v) CTAB with various amounts of BHABDI over the range $0.005-0.035 \mathrm{mmol} \mathrm{L}^{-1}$ was subjected to the flotation preconcentration process and results are depicted in Figure 4. At above concentration of ions, $>98 \%$ flotation efficiency was achieved for a BHABDI concentration of $0.012 \mathrm{mM}$, which was chosen for subsequent experiments. It is worth mentioning that the presence of excess amounts of the ligands revealed no adverse effect on the flotation process. This is an advantageous point, as the procedure could thus be applied to the analysis of these ions in real samples.

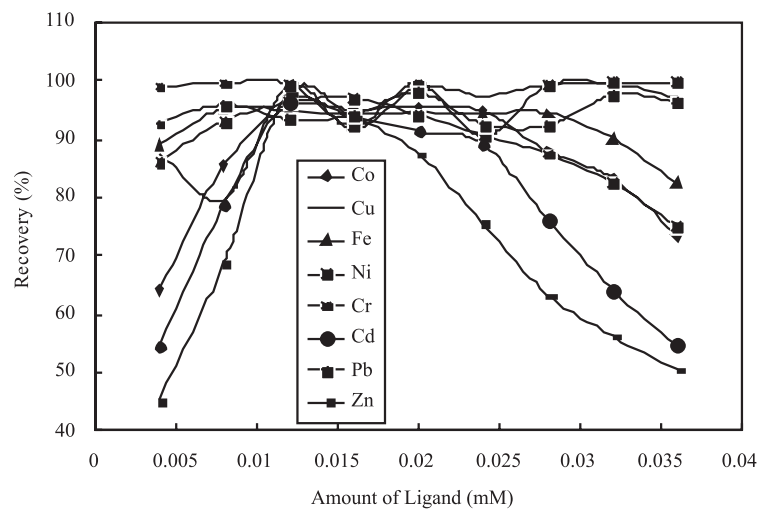

Figure 4. Effect of amount of ligand on the recoveries of analyte ions $(N=3)$

\section{Effect of $\mathrm{KNO}_{3}$ concentration}

$\mathrm{KNO}_{3}$ was investigated as electrolyte in the concentration range from $0.5 \mathrm{~mol} \mathrm{~L}^{-1}$ to saturated and the highest $\mathrm{Cr}^{3+}, \mathrm{Cu}^{2+}, \mathrm{Co}^{2+}, \mathrm{Ni}^{2+}$, $\mathrm{Zn}^{2+}, \mathrm{Cd}^{2+}, \mathrm{Fe}^{3+}$ and $\mathrm{Pb}^{2+}$ ions recovery was obtained at $1.5 \mathrm{~mol} \mathrm{~L}^{-1}$ $\mathrm{KNO}_{3}$ concentration. The recovery decreased considerably with increasing $\mathrm{KNO}_{3}$ concentrations $\left(>1.5 \mathrm{~mol} \mathrm{~L}^{-1}\right)$. This effect might be explained by the additional surface charge when the $\mathrm{KNO}_{3}$ concentration is very high, thus changing the molecular structure of the surfactant and consequently the micelle formation process. It is necessary to emphasize that different blank solutions were also evaluated and no significant signal was obtained. In this way, 1.5 mol L $\mathrm{KNO}_{3}$ concentrations were used in all further experiments.

\section{Effect of methanol volume}

Since the surfactant-rich phase obtained after the preconcentration contains a high concentration of CTAB and at the same time, the volume obtained is rather small, Therefore, various concentration of different acid in methanol was added to the surfactant-rich phase after the separation of phases in order to facilitate its introduction into the nebulizer of atomic absorption spectrometer. There is an optimum volume $(8 \mathrm{~mL})$ with respect to metal ions recoveries. Smaller volumes of methanol were not tested because in this case it was not possible to quantitatively transfer the rich phase from surface solution for simultaneous determination of metal ions. There is an optimum volume of $8 \mathrm{~mL}$ of $2.0 \mathrm{~mol} \mathrm{~L}^{-1} \mathrm{HNO}_{3}$ in methanol. Smaller volumes of methanol were not tested because in this case it was not possible to quantitatively transfer the rich phase from test tubes to the graduated tubes and measuring the absorbance for all ions. For larger volumes of acidified methanol, dilution was clearly predominated, resulting in a gradual absorbance reduction.

\section{Effect of foreign ions}

Interferences studied were those related to the preconcentration step, cations that may react with BHABDI or species that may react with analytes and decrease the extraction efficiency. Before the application of the preconcentration method for the determination of analyte ions in samples with complicated matrix, the influences of some alkaline and alkaline earth ions and some transition metal ions on the recoveries of the analyte ions were also investigated. To perform this study, $750 \mathrm{~mL}$ of solution containing $400 \mathrm{ng} \mathrm{mL}^{-1}$ analyte ions and interferents ion in different interferents-to-analyte ratios in the presence of $0.02 \mathrm{mmol} \mathrm{L}^{-1} \mathrm{CTAB}$, were subjected to the complete procedure and results are given in Tables 3 and 4 . The tolerance limit is defined as the ion concentration causing a relative error smaller than $\pm 5 \%$ related to the preconcentration and determination of analytes. Metal ions were quantitatively recovered at large amounts for alkaline and earth alkaline ions and some anions.

\section{Characteristics of the method}

Table 5 gives the characteristic performance of the proposed method of standard solutions subjected to the entire procedure. To determine the standard deviation of the method, 5 samples were floated, i.e. extracted by the recommended procedure and then the concentrations of metal ions were determined by FAAS. The detection limit of the method (DL) was estimated as three times the standard deviation (sd) of the blank. The values of DL were calculated as 2.3, 1.7, 2.2, 2.2 1.4, 1.5, 2.3 and $2.9 \mathrm{ng} \mathrm{mL}^{-1} \mathrm{Cr}^{3+}, \mathrm{Cu}^{2+}, \mathrm{Co}^{2+}, \mathrm{Ni}^{2+}, \mathrm{Zn}^{2+}$, $\mathrm{Cd}^{2+}, \mathrm{Fe}^{3+}$ and $\mathrm{Pb}^{2+}$ respectively. The preconcentration factor of the proposed method is about 125 . 
Table 3. Effects of the matrix ions on the recoveries of the examined metal ions $(\mathrm{N}=3)$

\begin{tabular}{lcr}
\hline Ion & Added as & Tolerance limit, $\mathrm{mg} \mathrm{L}^{-1}$ \\
\hline $\mathrm{Ba}^{2+}, \mathrm{Cl}^{-}, \mathrm{K}^{+}, \mathrm{Na}^{+}, \mathrm{Mg}^{2+}, \mathrm{HCO}_{3}^{-}, \mathrm{PO}_{4}^{3-}$ & $\mathrm{KCl}, \mathrm{NaCl}, \mathrm{MgCl}_{2}, \mathrm{Ba}\left(\mathrm{NO}_{3}\right)_{2} \mathrm{NaHCO}_{3,} \mathrm{Na}_{3} \mathrm{PO}_{4}$ & 1000 \\
$\mathrm{Mn}^{2+}, \mathrm{Ba}^{2+}, \mathrm{Ca}^{2+}, \mathrm{Bi}^{3+}, \mathrm{Ag}^{+}, \mathrm{Al}^{3+}, \mathrm{Cr}^{3+}, \mathrm{Hg}^{2+}$ & Nitrate salts & 1000 \\
\hline
\end{tabular}

Table 4. Continue effect of analyte ion on metal ions flotation recovery

\begin{tabular}{lcccccccc}
\hline & \multicolumn{8}{c}{ Recovery, \% } \\
\hline Metals (100 fold) & $\mathrm{Cu}$ & $\mathrm{Co}$ & $\mathrm{Cr}$ & $\mathrm{Fe}$ & $\mathrm{Ni}$ & $\mathrm{Cd}$ & $\mathrm{Pb}$ & $\mathrm{Zn}$ \\
$\mathrm{Zn}$ & 98.9 & 98.2 & 99.8 & 99.2 & 97.6 & 92.2 & 99.8 & - \\
$\mathrm{Co}, \mathrm{Zn}$ & 94.1 & - & 98.6 & 99 & 98.1 & 90.8 & 99.3 & - \\
$\mathrm{Co}, \mathrm{Cr}, \mathrm{Cu}, \mathrm{Pb}$ & - & - & - & 99.2 & 99.6 & 67.4 & - & 98.3 \\
$\mathrm{Co}, \mathrm{Cd}, \mathrm{Zn}$ & 98.3 & - & 99.7 & 99.9 & 98.4 & - & 99.7 & - \\
$\mathrm{Co}, \mathrm{Cd}, \mathrm{Cu}, \mathrm{Zn}$ & - & - & 98.8 & 99.9 & 98.7 & - & 99.6 & - \\
$\mathrm{Cr}, \mathrm{Fe}, \mathrm{Ni}, \mathrm{Pb}$ & 99.5 & 99.2 & - & - & - & 94.6 & - & 86.9 \\
\hline
\end{tabular}

\section{Flotation mechanism}

In studies concerning separation via flotation, the role of surfactant is very important. The nature of interaction between CTAB surfactant and complex formed must be studied to approach the actual mechanism of flotation. The proposed mechanism may proceed through a physical interaction or by forming a hydrogen bond between the hydrophilic part of CTAB and the active sites in the ligand complex, or by an interaction between $\mathrm{CTAB}$ and complex, formed in solution, through a coordinate bond forming a self-floatable (M-L-CTAB) spe- cies. In such cases, the hydrophilic part of the surfactant attaches to air bubbles and floats, thus separating the analyte-containing species.

In our investigation, the first proposal is more logical. This suggestion has been confirmed based on the flowing observation and experimental data: 1 ) the metal content of the solid complexes isolated in the absence and presence of CTAB excludes CTAB coordination. 2) The floated species have the same color as the obtained in the aqueous solution (especially in high reactants concentration). 3) The color intensity of the scum layer was affected by time. It should be noted that the color fading of the sublate begins after at least $5 \mathrm{~h}$ after flotation; such a time is more than enough for our determination. 4) It was observed that increasing the temperature decreases the separation percentage, reflecting that the physical force between CTAB and the M- BHABDI complex is destroyed by heating. 5) The spectra of the $\mathrm{M}$ - BHABDI complex isolated in the absence and presence of CTAB are identical, reflecting the fact that there is no coordinate or hydrogen contribution between CTAB and the M- BHABDI complex.

\section{Applications}

We have explored the feasibility of the methodology using preconcentration with BHABDI in surfactant media for the determination of $\mathrm{Cr}^{3+}, \mathrm{Cu}^{2+}, \mathrm{Co}^{2+}, \mathrm{Ni}^{2+}, \mathrm{Zn}^{2+}, \mathrm{Cd}^{2+}, \mathrm{Fe}^{3+}$ and $\mathrm{Pb}^{2+}$ ions in different

Table 5. Specification of presented method at optimum conditions for each element

\begin{tabular}{lcccccccc}
\hline Parameters & $\mathrm{Fe}$ & $\mathrm{Cu}$ & $\mathrm{Ni}$ & $\mathrm{Pb}$ & $\mathrm{Co}$ & $\mathrm{Cr}$ & $\mathrm{Zn}$ \\
\hline Linear range $\left(\mu \mathrm{g} \mathrm{mL}^{-1}\right)$ & $0.03-0.59$ & $0.01-0.64$ & $0.015-0.43$ & $0.03-0.72$ & $0.02-0.66$ & $0.02-0.48$ & $0.01-0.38$ & $0.01-0.27$ \\
Detection limit $\left(\mathrm{ng} \mathrm{mL}^{-1}\right)$ & 2.3 & 1.7 & 1.9 & 2.9 & 2.2 & 2.3 & 1.4 & 1.5 \\
RSD \% & 2.3 & 2.1 & 2.2 & 2.4 & 2.4 & 2.3 & 2.4 & 2.5 \\
Recovery \% & 97.8 & 96.1 & 95.6 & 96.2 & 97.8 & 97.9 & 98.0 & 97.3 \\
\hline
\end{tabular}

Table 6. Recovery studies of trace metal ions from some real samples

\begin{tabular}{|c|c|c|c|c|c|c|c|}
\hline \multirow[b]{2}{*}{ Ion } & \multirow[b]{2}{*}{ Added $\left(\mu \mathrm{g} \mathrm{g}^{-1}\right)$} & \multicolumn{3}{|c|}{ Allium Cepal } & \multicolumn{3}{|c|}{ Tomato } \\
\hline & & Found $\left(\mu \mathrm{g} \mathrm{g}^{-1}\right)$ & RSD \% & Recovery $\%$ & Found $\left(\mu \mathrm{g} \mathrm{g}^{-1}\right)$ & RSD \% & Recovery $\%$ \\
\hline \multirow{2}{*}{$\mathrm{Pb}$} & 0 & 0.86 & 3.2 & ---- & 0.93 & 3.4 & - \\
\hline & 0.5 & 1.38 & 2.4 & 104.0 & 1.46 & 2.7 & 106.0 \\
\hline \multirow{2}{*}{$\mathrm{Cd}$} & 0 & 1.1 & 3.6 & ---- & 1.13 & 3.7 & --- \\
\hline & 0.5 & 1.63 & 2.5 & 106.0 & 1.64 & 3.0 & 102.0 \\
\hline \multirow{2}{*}{$\mathrm{Zn}$} & 0 & 0.52 & 3.2 & --- & 0.92 & 3.6 & ---- \\
\hline & 0.5 & 1.03 & 2.1 & 102.0 & 1.45 & 2.8 & 106.0 \\
\hline \multirow{2}{*}{$\mathrm{Cu}$} & 0 & 0.29 & 3.3 & ---- & 2.21 & 3.3 & --- \\
\hline & 0.5 & 0.81 & 2.3 & 104.0 & 2.73 & 2.6 & 104.0 \\
\hline \multirow{2}{*}{$\mathrm{Cr}$} & 0 & 0.35 & 2.9 & --- & 2.09 & 3.1 & --- \\
\hline & 0.5 & 0.87 & 2.4 & 104.0 & 2.61 & 2.6 & 104.0 \\
\hline \multirow{2}{*}{ Co } & 0 & 0.47 & 3.1 & ---- & 0.73 & 3.5 & --- \\
\hline & 0.5 & 0.99 & 2.7 & 104.0 & 1.25 & 2.4 & 104.0 \\
\hline \multirow{2}{*}{$\mathrm{Fe}$} & 0 & 1.73 & 3.0 & ---- & 1.91 & 3.1 & ---- \\
\hline & 0.5 & 2.25 & 2.3 & 104.0 & 2.43 & 2.0 & 104.0 \\
\hline \multirow{2}{*}{$\mathrm{Ni}$} & 0 & 0.14 & 2.9 & ---- & 1.02 & 3.2 & ---- \\
\hline & 0.5 & 0.67 & 2.1 & 106.0 & 1.54 & 2.2 & 104.0 \\
\hline
\end{tabular}


Table 7. Recovery studies of trace metal ions from some real samples

\begin{tabular}{|c|c|c|c|c|c|c|c|c|c|c|}
\hline \multirow[b]{2}{*}{ Ion } & \multirow[b]{2}{*}{ Added $\left(\mu \mathrm{g} \mathrm{g}^{-1}\right)$} & \multicolumn{3}{|c|}{ Citrus aurantium L. } & \multicolumn{3}{|c|}{ Rose - Canina } & \multicolumn{3}{|c|}{ Fumaria parviflora } \\
\hline & & Found $\left(\mu \mathrm{g} \mathrm{g}^{-1}\right)$ & RSD \% & Recovery \% & Found $\left(\mu \mathrm{g} \mathrm{g}^{-1}\right)$ & RSD \% & Recovery \% & Found $\left(\mu \mathrm{g} \mathrm{g}^{-1}\right)$ & RSD \% & Recovery \% \\
\hline \multirow{2}{*}{$\mathrm{Pb}$} & 0 & 0.202 & 3.6 & --- & 0.228 & 3.8 & --- & 0.8 & 2.9 & --- \\
\hline & 1.0 & 1.214 & 2.9 & 101.2 & 1.30 & 3.0 & 107.2 & 1.84 & 2.4 & 104.0 \\
\hline \multirow{2}{*}{$\mathrm{Cd}$} & 0 & 0.405 & 3.5 & --- & 0.201 & 3.8 & ---- & 0.71 & 3.1 & --- \\
\hline & 1.0 & 1.398 & 2.7 & 99.3 & 1.212 & 3.3 & 101.1 & 1.76 & 2.2 & 105.0 \\
\hline \multirow{2}{*}{$\mathrm{Zn}$} & 0 & 0.382 & 3.5 & --- & 0.728 & 3.5 & --- & 0.155 & 3.4 & --- \\
\hline & 1.0 & 1.393 & 2.7 & 101.1 & 1.74 & 3.1 & 101.2 & 1.169 & 2.3 & 101.4 \\
\hline \multirow{2}{*}{$\mathrm{Cu}$} & 0 & 0.505 & 3.6 & --- & 0.316 & 3.8 & --- & 0.118 & 3.0 & --- \\
\hline & 1.0 & 1.519 & 2.6 & 101.4 & 1.330 & 3.3 & 101.4 & 1.14 & 2.6 & 102.2 \\
\hline \multirow{2}{*}{$\mathrm{Cr}$} & 0 & 0.601 & 3.5 & --- & 0.888 & 3.9 & --- & 0.502 & 3.3 & --- \\
\hline & 1.0 & 1.618 & 2.6 & 101.8 & 1.874 & 3.1 & 98.6 & 1.530 & 2.8 & 102.8 \\
\hline \multirow{2}{*}{ Co } & 0 & 0.321 & 3.7 & --- & 0.140 & 3.0 & --- & 0.435 & 3.4 & - \\
\hline & 1.0 & 1.339 & 2.6 & 101.8 & 1.130 & 2.7 & 99.0 & 1.391 & 3.0 & 95.6 \\
\hline \multirow{2}{*}{$\mathrm{Fe}$} & 0 & 0.247 & 3.6 & --- & 0.265 & 3.1 & --- & 0.362 & 3.1 & --- \\
\hline & 1.0 & 1.259 & 2.8 & 101.2 & 1.278 & 2.6 & 101.3 & 1.359 & 2.7 & 99.7 \\
\hline \multirow{2}{*}{$\mathrm{Ni}$} & 0 & 0.926 & 3.4 & --- & 0.188 & 3.3 & --- & 0.261 & 3.7 & ---- \\
\hline & 1.0 & 1.939 & 2.7 & 101.3 & 1.199 & 2.5 & 101.1 & 1.248 & 3.0 & 98.7 \\
\hline
\end{tabular}

matrices including treated according to experimental section. The results are presented in Table 6 and 7. The satisfactory recoveries of analytes and low RSD of spiked samples which confirmed by standard addition method show the capability of the system in the determination of analytes in such real samples with complicated matrix.

\section{CONCLUSION}

The flotation of $\mathrm{Cr}^{3+}, \mathrm{Cu}^{2+}, \mathrm{Co}^{2+}, \mathrm{Ni}^{2+}, \mathrm{Zn}^{2+}, \mathrm{Pb}^{2+}, \mathrm{Cd}^{2+}$ and $\mathrm{Fe}^{3+}$ ions with BHABDI into the phase of cationic surfactant CTAB has been investigated. The sensitivity, metrological characteristics, ecological safety, simplicity and convenience of the suggested procedure are superior with respect to the methods based on the extraction with organic solvents. ${ }^{38-41}$ The present method has following advantages over reported methods: (1) synthesized organic reagent could be synthesized in our laboratory with high efficiency and low cost. This reagent is distinct in terms of sensitivity, selectivity towards metal ions. (2) Optimum volume of the eluting solution and low consumption of chemical reagents obtained by using the present methodology permitted to design an extraction strategy that posses one of the following advantages presenting robustness, low cost, low detection limits and good S.D.s, good extraction efficiency and lower toxicity than those previously reported in literature. ${ }^{39-47}$

\section{REFERENCES}

1. Stalikas, C. D.; Trends Anal. Chem. 2002, 21, 343.

2. Dogan, M.; Türkyilmaz, A.; Alkan, M.; Demirba, O.; Desalination 2009, 238, 257.

3. Furusho, Y.; Sabarudin, A.; Hakim, L.; Oshita, K.; Oshima, M.; Motomizu, S.; Anal. Sci. 2009, 25, 51.

4. Cespon, R. M.; Yebra, M. C.; Microchim. Acta 2008, 164, 225.

5. Kazi, T. G.; Jalbani, N.; Arain, M. B.; Jamali, M. K.; Afridi, H. I.; Sarfraz, R. A.; Shah, A. Q.; J. Hazard. Mater. 2009, 163, 302.

6. Jayaraju, N.; Reddy, B. C. S. R.; Reddy, K. R.; Environ. Geol. 2009, 56 , 1205.

7. Yildirim, Y.; Gonulalan, Z.; Narin, I.; Soylak, M. ; Environ. Monit. Assessment 2009, 149, 223.
8. Mauri-Aucejo, A. R.; Campos-Candel, A.; Marin-Saez, R.; LlobatEstelles, M.; Atom. Spectrosc. 2008, 29, 217.

9. Ghaedi, M.; Fathi, M. R.; Marahel, F.; Ahmadi, F.; Fresenius Environ. Bull. 2005, 14, 1158.

10. Soylak, M.; Narin, I.; Bezerra, M. A.; Ferreira, S. L. C.; Talanta 2005, 65,895 .

11. Tuzen, M.; Soylak, M.; J. Hazard. Mater. 2006, 129, 266.

12. Haji Shabani, A. M.; Dadfarnia, S.; Motavaselian, F.; Ahmadi, S. H.; J. Hazard. Mater. 2009, 162, 373.

13. Ghaedi, M.; Fathi, M. R.; Shokrollahi, A.; Shajarat, F.; Anal. Lett. 2006, 39, 1171; Ghaedi, M.; Shokrollahi, A.; Kianfar, A. H.; Mirsadeghi, A. S.; Pourfarokhi, A.; Soylak, M.; J. Hazard. Mater. 2008, 154, 128.

14. Manzoori, J. L.; Amjadi, M.; Abulhassani, J.; Talanta 2009, 77, 1539.

15. Soylak, M.; Elçi, L.; Do an, M.; Fresenius Environ. Bull. 1996, 5, 148.

16. Ghaedi, M.; Ahmadi, F.; Soylak, M.; J. Hazard. Mater. 2007, 147, 226; Ghaedi, M.; Ahmadi, F.; Soylak, M.; Ann. Chim. 2007, 97, 277.

17. Stafilov, T.; Spectrochim. Acta 2000, 55, 893.

18. Robinson, P.; Chem. Geol. 1980, 28, 135.

19. Nakamura, T.; Okubo, K.; Sato, J.; Anal. Chim. Acta 1988, 209, 287.

20. Lazaru, A.; Stafilov, T.; Geologica Macedonica 1993, 7, 73.

21. Manning, D. C.; Slavin, W.; Anal. Chem. 1978, 50, 1234.

22. Ure, M.; Thomas, R.; Litlejohn, D.; Int. J. Environ. Anal. Chem. 1993, $51,65$.

23. Ilgen, G.; Fiedler, J. J.; Chem. Erde 1991, 51, 141.

24. Stendal, H.; Chem. Erde 1980, 39, 276.

25. Donaldson, E. M.; Talanta 1989, 36, 543.

26. Savitsky, V. N.; Peleshenko, V. I.; Osadchii, V. I.; Mikhailenko, V. P.; Gidrochim. Mater. 1990, 109, 152.

27. Mizuike, A.; Flotation, in Enrichment Techniques for Inorganic Trace Analysis, Springer-Verlag: Heidelberg, 1983.

28. Zolotov, Y. A.; Kuzmin, N. M.; Preconcentration of Trace Elements, Elsevier: Amsterdam, 1990.

29. Caballero, M.; Cela, R.; Pérez-Bustamante, J. A.; Talanta 1990, 37, 275.

30. Kim, Y. S.; Choi, Y. S.; Lee, W.; Bull. Korean Chem. Soc.2002, 23, 1381.

31. Tani, H.; Kamidate, T.; Watanabe, T.; J. Chromatogr., A 1997, 780, 229.

32. Borges, D. L. G.; Veiga, M. A. M. S.; Frescura, V. L. A.; Welz, B.; Curtius, A. J.; J. Anal. At. Spectrom. 2003, 18, 501.

33. Kim, Y. S.; Choi, Y. S.; Lee, W.; Lee, Y.; Bull. Korean Chem. Soc. 2001, 22,821 . 
34. Kabil, A.; Ak1, M. A.; Khalifa, M. E.; Anal. Sci. 1999, 15, 433.

35. Shokrollahi, A.; Ghaedi, M.; Ghaedi, H.; Chin. J. Chem. Soc. 2007, 54, 933.

36. Karimi, H.; Ghaedi, M.; Shokrollahi, A.; Rajabi, H. R.; Soylak, M.; Karami, B.; J. Hazard. Mater. 2008, 151, 26.

37. Ghaedi, M.; Asadpour, E.; Vafaie, A.; Bull. Chem. Soc. Jpn. 2006, 76, 341.

38. Andoh, T.; Tsukinoki, S.; Itoh, O.; Akama, Y.; Bunseki Kagaku 2008, $57,1027$.

39. Li, Z.; Chang, X.; Zou, X.; Zhu, X.; Nie, R.; Hu, Z.; Li, R.; Anal. Chim. Acta 2009, 632, 272.
40. Ghorbani, A.; Farahani, M. M.; Rabbani, M.; Aflaki, F.; Hosain, S. W.; Measurement Sci. Rev. 2008, 8, 151.

41. Narin, I.; Soylak, M.; Talanta 2003, 60, 215.

42. Sharma, R. K.; Pant, P.; J. Hazard. Mater. 2009, 163, 295.

43. Parham, H.; Pourreza, N.; Rahbar, N.; J. Hazard. Mater. 2009, 163, 588.

44. Chen, H.; Shen, M.; Xue, A. F.; Li, S. Q.; Pan, S. Y.; Spectrosc. Spectr. Anal. 2009, 29, 1422.

45. Faraji, M.; Yamini, Y.; Shariati, S.; J. Hazard. Mater. 2009, 166, 1383.

46. Wu, H.; Wen, H.; Han, B.; Du, B.; Lu, J.; Tian, J.; Microchim. Acta 2009, 166, 41.

47. Soylak, M.; Elçi, L.; Doğan, M.; Anal. Lett. 1993, 26, 1997. 